THE OHIO STATE UNIVERSITY

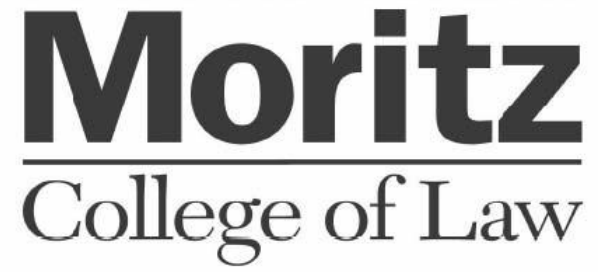

\title{
NLRB v. New Vista Nursing and Rehabilitation: The Third Circuit Further Fuels the Constitutional Conflict Over Recess Appointments
}

Peter M. Shane

Public Law and Legal Theory Working

Paper Series

No. 218

May 24, 2013

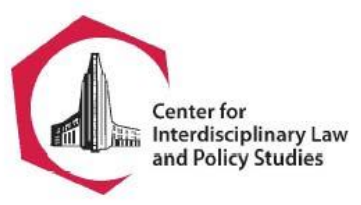

This working paper series is co-sponsored by the Center for Interdisciplinary Law and Policy Studies at the Moritz College of Law

This paper can be downloaded without charge from the Social Science Research Network Electronic Paper Collection: http://ssrn.com/abstract=2284316 


\section{Bloomberg
BNA}

\section{Daily Report for Executives ${ }^{\text {TM }}$}

Reproduced with permission from Daily Report for Executives, 101 DER B-1, 05/24/2013. Copyright $\odot 2013$ by The

Bureau of National Affairs, Inc. (800-372-1033) http://www.bna.com

\section{Government Operations}

A new opinion by the Third Circuit that followed the D.C. Circuit in invalidating President Obama's use of the recess-appointments power may actually strengthen the president's case, Peter M. Shane of Ohio State University law school argues.

The new decision may focus the Supreme Court's attention on "just how much legal uncertainty the Court could create by holding intrasession recess appointments invalid," he says. Beyond that, the new decision "devastates the D.C. Circuit's textualist reading of the Recess Appointments Clause." The Third Circuit's more policy-oriented analysis, if pursued, points toward upholding recess appointments.

\section{NLRB v. New Vista Nursing and Rehabilitation: The Third Circuit Further Fuels the Constitutional Conflict Over Recess Appointments}

\section{Peter M. Shane}

B y a 2-1 vote, the U.S. Court of Appeals for the Third Circuit has handed down the year's second appellate decision invalidating President Obama's exercise of his recess appointments power. ${ }^{1}$ Like the D.C. Circuit's Noel Canning v. NLRB ${ }^{2}$ opinion, the Third Circuit case deals with an appointment made during a period of adjournment that occurred in the middle of a session of the U.S. Senate-a so-called "intrasession recess."

As I described in an earlier Insight, ${ }^{3}$ the D.C. Circuit opinion in Noel Canning invalidated President Obama's

${ }^{1}$ NLRB v. New Vista Nursing and Rehabilitation, No. 113440 (3d Cir. May 16, 2013), available at http:// www.ca3.uscourts.gov/opinarch/113440p.pdf (hereafter, "New Vista Nursing"').

${ }^{2}$ Noel Canning v. NLRB, 705 F.3d 490 (D.C. Cir. 2013).

${ }^{3}$ Peter M. Shane, The Future of Recess Appointments in Light of Noel Canning $v$. NLRB, (93 DER B-1, 5/14/13).

Peter M. Shane is the Jacob E. Davis and Jacob E. Davis II Chair in Law at Ohio State University's Moritz College of Law. The opinions expressed are those of the author.
2012 recess appointments for three NLRB commissioners. The court offered a highly debatable textualist dissection of the Recess Appointments Clause ${ }^{4}$ that ignored not only strong arguments against the court's position, but potentially stronger arguments in support. The D.C. Circuit also held that presidents may make recess appointments only when vacancies first arise during a Senate recess. This is a conclusion that the Supreme Court is unlikely to endorse, and reaches an issue that the D.C. Circuit did not need to explore. The Third Circuit opinion does not address it.

The new decision, NLRB v. New Vista Nursing and Rehabilitation, holds invalid President Obama's appointment to the Board of attorney Craig Becker. The President appointed Mr. Becker during a two-week Senate recess starting in late March, 2010. The Becker recess appointment-occurring eight-and-a-half months after his conventional nomination-does not present the knotty question that the D.C. Circuit confronted of whether pro forma Senate sessions effectively prevent the Senate from going into recess.

\footnotetext{
${ }^{4}$ U.S. Const., Art. II, § 2, par. 3 ("The President shall have Power to fill up all Vacancies that may happen during the Recess of the Senate, by granting Commissions which shall expire at the End of their next Session.")
} 
The Third Circuit held, however, that, regardless of duration, the only recess that permits a recess appointment is a recess between, not during, sessions of the U.S. Senate. Member Becker was a signatory to 600 published NLRB opinions during his tenure, so the number of Board actions vulnerable to legal challenge should the Third Circuit opinion be upheld is enormous. $^{5}$

Government's Loss Could Help It. The outcome of the Third Circuit case is unwarranted, and the majority opinion is vulnerable to some technical objections. Unlike the Noel Canning opinion, however, the Third Circuit decision is at least worthy of its subject. Its author, Judge D. Brooks Smith, wrestles conscientiously with the issue presented. Although he reaches the same bottom-line result as the D.C. Circuit, his opinion will arguably help the government when the Supreme Court takes up the recess appointments issue, which, after Noel Canning, it is almost certainly going to do. First, because the case reaches back to a 2010 appointment, the decision implicitly underscores just how much more is at stake in terms of orderly public administration beyond the NLRB order at issue in Noel Canning. But, even more remarkably, Judge Smith's linguistic analysis devastates the D.C. Circuit's textualist reading of the Recess Appointments Clause. His foray into late $18^{\text {th }}$ century understanding of the clause may actually prove more helpful to the government than to Noel Canning in the higher court.

Judge Smith reaches the wrong result, in my view, for three main reasons.

- First, although he properly insists that the Recess Appointments Clause be interpreted in light of the Framers' purposes, he reads those purposes too narrowly. He ignores that the Framers designed a process in which the President was to take the leading hand in choosing Officers of the United States.

- Second, he fails to deal with the problem of unanticipated conditions.

- Third, he overestimates the degree to which the Constitution prevents abuses of power through textual specificity rather than conferring on Congress and the executive largely discretionary, but mutually checking powers that implicitly create incentives for interbranch accommodation.

\section{The Constitution Under Unanticipated Conditions: Is the USAF Constitutional?}

It may be that you have a friend who likes to thump the table and, in imitation of Justice Antonin Scalia, insist that the Constitution does not change. I recommend that you ask your friend, then, why the Constitution permits an Air Force. The Army Clause of the Constitution allows Congress "[t]o raise and support Armies."6

\footnotetext{
${ }^{5}$ I derived this figure using Westlaw to search for documents including the name "Becker" that the Board issued between April 5, 2010 and January 3, 2012, the dates of his tenure. Fourteen of these opinions were rendered before June 29, 2010, when Brian Hayes was confirmed as a third member of the Board. These opinions are already subject to challenge under New Process Steel v. NLRB, 130 S. Ct. 2635 (2010), which held that the Board's lawful exercise of jurisdiction required the participation of three duly appointed members.

${ }^{6}$ U.S. Const., Art. I, § 8, par. 12.
}

The Navy Clause permits Congress to "provide and maintain a Navy."7 The President is designated "Commander in Chief of the Army and Navy of the United States," 8 and of no other service. I am quite confident that the ordinary meaning of neither "Army," nor "Navy," in 1789 included people conducting combat in airborne machines. For all anyone knows, the Framers would have abhorred the idea of human flight. Remember Icarus? They would have.

If your friend is clever, he or she might respond that Congress is also allowed by Article I to "provide for the common Defense and general welfare of the United States," and the Air Force contributes to both. But this riposte shouldn't satisfy a constitutional originalist. That's because such a reading of the Common Defense Clause in 1789 would have made the Army and Navy Clauses superfluous.

If the Framers would have read the Common Defense Clause as authorizing the creation of an entire branch of the armed services, then that same Common Defense Clause would have been sufficient to permit Congress to create an Army and a Navy. The Framers obviously did not read the clause that way. Instead, when they wanted to allow the creation of armed services, they inserted into their charter of Congress's powers a specific Army Clause and a specific Navy Clause. If we in 2013 are now to limit our reading of the Common Defense Clause to what the Framers must have imagined its scope to be, that clause should not be read as permitting Congress to create a separate Air Force. Like ordinary readers of the Constitution in 1789 , we should limit congressional spending under the Common Defense Clause to much less ambitious projects, like building forts or financing military academies.

\section{What changes is not the language of the Constitution, or the semantic meaning of its words, but the acceptable implications of that language under unanticipated circumstances.}

Thankfully, that's not how we read the Common Defense Clause. The Framers did not foresee that enemies of the United States would someday be able to attack our army and navy with airborne machines. But they wanted the United States kept safe. It makes no sense to operationalize the Framers' language in a way that would leave the United States defenseless in the face of other nations' air power. Whatever the Framers anticipated "Army" and "Navy," would mean, they would have wanted our defenses to keep pace with new challenges. Thus, we now read the authorization as encompassing all "armed forces." What has changed is not the language of the Constitution, or even the semantic meaning of its words. What has changed are the acceptable implications of that language under unanticipated circumstances.

\footnotetext{
${ }^{7}$ U.S. Const., Art. I, § 8, par. 13.

${ }^{8}$ U.S. Const., Art. II, $\$ 2$, par. 1.

${ }^{9}$ U.S. Const., Art. I, $\S 8$, par. 1.
} 
The Constitution frequently makes this sort of adaptation easier through its use of general language. In drafting the Fourth Amendment, for example, the Framers presumably had in mind a paradigm case of an evil to be prevented - namely, the unwarranted physical trespass on private property by government agents seeking to take hold of a person's tangible possessions. But that's not the language they used. Instead, they created a right against "unreasonable searches and seizures." The Framers did not act in anticipation of electronic technology allowing eavesdropping on private conversations without physical trespass. But the language they used allows courts to recognize wiretapping without a warrant as the kind of evil that the Framers of the Fourth Amendment would have targeted if they just had a crystal ball. The words of the Constitution remain constant, but their application changes.

For similar reasons, we have seen the expansion of "freedom of speech," "due process," "cruel and unusual punishment," and "equal protection," beyond those paradigm cases that likely predominated in the drafters' imagination. Such an interpretive process does no violence to the semantic meaning of the Constitution's words. The point is to operationalize the text in light of circumstances the Framers did not encounter in order to accomplish the purposes that underlay the constitutional design. This same logic applies to recess appointments.

\section{NLRB v. New Vista Nursing and Rehabilitation: The Smaller Problems}

Before observing how the Third Circuit simply ignored the problem of unanticipated circumstances, it's worth pointing out two smaller problems with its opinion.

One is that, in reaching its constitutional judgment, the majority just skips the step of determining "whether the Board's substantive decision was correct" under the National Labor Relations Act. ${ }^{10}$ The omission is strange in an otherwise careful opinion because the court, with regard to another side issue, explicitly recognizes the venerable rule of not reaching a constitutional question if a case may be decided on narrower grounds. ${ }^{11}$ If the court were to find the NLRB order improper under the terms of the governing statute or the Administrative Procedure Act, it would not have to decide on the constitutionality of intrasession recess appointments. Skipping this step creates the unfortunate impression that the court was going out of its way to have a say on the Constitution. Even when judges recognize that a constitutional issue is "hot," they are supposed to forebear from deciding it unless a constitutional decision is actually necessary.

The second of the smaller problems is that the court fails to recognize that the NLRB's understanding of what constitutes a recess actually originated not with the NLRB or even the Justice Department, but with the Senate itself, whose authority the court's majority is at pains to protect against executive encroachment. The court quotes the following proffered definition of recess from a 1921 opinion of Attorney General Harry Daugherty: "[T]he essential inquiry . . . is this: Is the adjourn-

\footnotetext{
${ }^{10}$ New Vista Nursing, supra note 1, at 102.

${ }^{11}$ Id. at 20.
}

ment of such duration that the members of the Senate owe no duty of attendance? Is its chamber empty? Is the Senate absent so that it can not [sic] receive communications from the President or participate as a body in making appointments?",12

\section{“The word 'recess' is one of ordinary, not \\ technical signification, and it is evidently used in}

\author{
the constitutional provision in its common and \\ popular sense." \\ Senate Report, 1905
}

But the Attorney General lifted this definition from a 1905 Senate report protesting the most audacious use of recess appointment power in history. Theodore Roosevelt had used a moment's intersession recess in 1903 to make 193 executive branch appointments, literally between two raps of a gavel. ${ }^{13}$ The Senate responded with what became the Daugherty test, but prefaced by this sentence: "The word 'recess' is one of ordinary, not technical signification, and it is evidently used in the constitutional provision in its common and popular sense."14

A 1905 Senate report is, of course, not authoritative on a question of constitutional interpretation. The Third Circuit would have done well to note, however, that a preference for interpreting the clause according to a practical sense of "recess" has not been limited to the executive branch.

\section{The Recess Appointment Power Under Unanticipated Circumstances}

The problems just mentioned do not necessarily point to a different outcome in the Third Circuit case. The NLRB order was probably valid under its statutory authority. Even if it had adjudicated that preliminary question, the Third Circuit would still have proceeded to the constitutional challenge. Likewise, even if the Court had acknowledged the 1905 Senate report, it might not have given it great weight.

Much more problematic, however, is the court's unjustifiably narrow understanding of the purposes surrounding the design of the federal appointments process, and its failure to consider the implications of historical change.

Unlike the D.C. Circuit, the Third Circuit in Noel Canning concluded that a now-popular version of socalled constitutional originalism - the search for the ordinary meaning of the Recess Appointments Clause as its words would have been read in 1789 - is inadequate

\footnotetext{
1233 Op. Att'y Gen. 20, 25 (1921).

${ }^{13} \mathrm{Al}$ Kamen, "Recess appointments: Nobody did them like Teddy," Wash. Post. (Dec. 12, 2011), available at http:// www.washingtonpost.com/blogs/in-the-loop/post/recessappointments-nobody-did-them-like-teddy/2011/12/08/ gIQAJK1IgO blog.html.

${ }^{14}$ S. Rept. No. 4839, 58th Cong., 3rd Sess. 3823-3824 (1905), quoted in Precedents of the House of Representatives, $\S 6687$, at $852-853$.
} 
to dictate a choice between allowing and prohibiting intrasession appointments. As the court concedes: "The word 'recess' lacks a natural meaning that clearly identifies whether it includes only intersession breaks or also includes intrasession breaks, whether they be of a certain duration or a period of unavailability. Dictionaries from the time of ratification provide definitions that can be read to support any of these definitions." ${ }^{15}$ Nor does contemporaneous government practice resolve the controversy: "[The] history [of state and federal government practice] shows," the court concludes, "that recess had at least two meanings at the time of ratification: either intersession breaks only or intersession breaks plus long intrasession breaks." 16

What tilts the court against intrasession recesses, however, is what it takes to be the Framers' understanding of the role of recess appointments in the overall design of the appointments process: "In The Federalist No. 67," the court writes, Alexander Hamilton "established that the President's recess appointment power is 'nothing more than a supplement' and an 'auxiliary method of appointment' to be used when 'the general method [of seeking the Senate's advice and consent] was inadequate." "17

\section{In Judge Brooks Smith's view, allowing intrasession} recess appointments would convert an "auxiliary" process into a kind of co-equal alternative.

In the court's view, allowing intrasession recess appointments would convert an "auxiliary" process into a kind of co-equal alternative. Allowing intrasession appointments would undermine what the court takes to be "a crucial aspect of the Clause's purpose: to preserve the Senate's advice-and-consent power by limiting the president's unilateral appointment power."18

The threshold difficulty with this reading, however, is that it ignores Hamilton's more general description of the President's and the Senate's appointment roles. In The Federalist, No. 76, Hamilton wrote that discretion in the choice of Officers was to rest essentially with the President: "[O]ne man of discernment," wrote Hamilton, "is better fitted to analyze and estimate the peculiar qualities adapted to particular offices, than a body of men of equal or perhaps even of superior discernment." The intended role of the Senate was to check potential favoritism or corruption. As Hamilton explained: "[The Senate] would be an excellent check upon a spirit of favoritism in the President, and would tend greatly to prevent the appointment of unfit characters from State prejudice, from family connection, from personal attachment, or from a view to popularity."

\footnotetext{
${ }^{15}$ New Vista Nursing, supra note 1 , at 40.

${ }^{16}$ Id. at 53

${ }^{17}$ Id. at 60 .

${ }^{18}$ Id. at 61 .
}

\section{The Senate is not authorized to shut down an} agency of government by refusing to vote on the

\author{
President's nominees.
}

What is completely missing from this view of the appointments process is any hint that the Senate is to play some sort of policy role equivalent to the President's in deciding who ought to staff the executive branch. The Senate is not authorized to shut down an agency of government by refusing to vote on the President's nominees.

The Third Circuit's reading of the Recess Appointments Clause threatens to turn this hierarchy of influence on its head. The Senate can effectively disable the executive branch from functioning by simply never voting on a President's choices. Judge Smith seems to find this unobjectionable, arguing that "the Senate's decision not to act on a nomination effectively is a rejection of that nomination," 19 which is within the Senate's prerogative. But there is a critical, unmistakable difference: Rejecting a nomination requires a majority vote. Ignoring a nomination does not. A blocking minority can defeat the majority's intention.

Hence, the problem of unanticipated circumstances: The Framers wrote a Constitution that failed to anticipate either the emergence political parties-they were hostile to the idea-or the filibuster. These "technologies" of politics have revolutionized the separation of powers just as other technologies have upended the meaning of interstate "commerce." Operationalizing the Recess Appointments Clause in a way that leaves the President all but defenseless in the face of partisan Senate intransigence makes no more sense than leaving the United States at the mercy of other nations' air forces. Clauses of the Constitution should be read to give effect to as much of the principled constitutional design as possible.

In his persuasive dissent, Judge Greenaway makes the point forcefully. "[T]he Recess Appointments Clause," he urges, "cannot be fully understood in isolation but only within the fabric and spirit of the Constitution as a whole. [The] Federalist papers, which describe the separation of our government's powers, instruct that the power of appointment must be coordinated so that no branch can 'possess, directly or indirectly, an overruling influence over the others. ",20 Yet, "overruling" is just what Senate obstructionism amounts to, made all the more odious when done without majority approval.

\section{Text Doesn't Stop Abuse, People Do}

Undergirding Judge Smith's analysis is an understandable concern for the potential of presidential abuse. If "recess" in the Recess Appointments Clause is treated to mean any period of adjournment regardless

\footnotetext{
19 Id. at 76 .

${ }^{20}$ Id. at 124 (Greenaway, Jr., J., dissenting), quoting The Federalist No. 48, at 308 (James Madison) (Clinton Rossiter ed., 1961)
} 
of duration, then a president, in theory, could engage in recess appointments over a weekend, or overnight, or even during a lunch hour. A bright-line reading of "recess" to mean only "intersession recess" presumably curbs this potential.

But the absence of bright-line constitutional rules to curb any branch's abuse of its powers is not a constitutional bug; in a world of interdependent, but competitive political institutions, it's a feature. There is no text limiting the laws a President may veto (or his reasons for vetoing them), the pardons he may issue, or the occasions on which he may convene Congress on his own initiative. His categorical textual powers are quite adequate, if asserted irresponsibly, to undermine both Congress and the judiciary.

Text also does little by itself to prevent Congress's abuse of its powers. The Constitution provides no clear definition of those "high crimes and misdemeanors" that would support an impeachment. The text creates no bar to a Congress intending to starve the government of any funds beyond the President's salary and salaries for the judiciary and for Congress. Congress may enact statutes, even over a President's veto, that enrich special interests, waste taxpayer money, and impose unnecessary or unhelpful regulations on the economy. And, of course, the Senate can shirk its confirmation responsibility by taking no votes on presidential nominees.

What the Framers expected, perhaps too optimistically, is that no branch would take its powers to the full limits of linguistic possibility because the text builds into the system incentives for mutual respect and accommodation. President Obama has attended to those incentives. Of the approximately 329 intrasession recess appointments conferred by presidents since 1981, President Obama has made only $29 .^{21} \mathrm{He}$ is the least active recess appointer despite having to endure the least cooperative Senate in recent history. The reason is presumably that, in his judgment, the institutional disincentives to evading the confirmation process outweigh the incentives for most recess appointments. That is the way the checks and balances are supposed to operate.

\section{Today, it is the prospect of recess appointments}

\section{that gives the President nearly the only leverage}

\section{he has to prevent a Senate, snarled up in minority \\ rule, from upending administrative agencies by sitting on nominations forever.}

But the Senate needs a balance of incentives and disincentives, too. In today's institutional climate, it is the prospect of recess appointments that gives the President nearly the only leverage he has to prevent a Senate, snarled up in minority rule, from upending administrative agencies by sitting on nominations forever.

${ }^{21}$ Henry Hogue, et al., The Noel Canning Decision and Recess Appointments Made from 1981-2013, at 4 (CRS Feb. 4, 2013) (tabulating presidential recess appointments since 1981).
The Third and D.C. Circuit opinions, if followed by the Supreme Court, will remove that leverage. The result, except when the same party controls both ends of Pennsylvania Avenue, will either be presidents hobbled in performing their duties or resorting to the kinds of constitutional trickery which-even if not inconsistent with the text-would be manifestly destructive of its spirit.

Consider that reading "recess" to mean "intersession recess" would actually be insufficient to prevent a truly usurpatious President from engaging in abuse if determined to do so. All a President intent on evading the Senate need do is obtain resignations from office holders "to take effect upon the adjournment of the Senate sine die." He could then execute a series of appointment letters "to take effect upon the effectiveness of the previous incumbent's resignation." With this technique, a President could unilaterally appoint the entire political layer of the executive branch on an annual basis without any Senate input whatever. Teddy Roosevelt would be proud.

John Marshall famously said of the process of judicial review, "we must never forget that it is a Constitution we are expounding." 22 That means discerning the document's meaning from a full view of the Framers' purposes, and taking advantage of the document's general language to fit its structures to unanticipated circumstances - whether of technology or of politics. A court cognizant of this duty ought to conclude that intrasession recess appointments are constitutional.

\section{Something More for the Justices to Ponder}

How New Vista Nursing will affect the Supreme Court remains to be seen. It seems a sure bet that the Court will grant the Government's petition for certiorari in Noel Canning and resolve that dispute. The Supreme Court could conceivably hold in Noel Canning either that intrasession recess appointments are categorically disallowed or that they are categorically permissible, regardless of duration. Either of such rulings would effectively decide New Vista Nursing as well. New Vista Nursing makes it less likely that the Supreme Court will resolve the issue, as the D.C. Circuit did, on largely semantic grounds. The Third Circuit's implicit critique of the D.C. Circuit methodology is too strong to ignore.

If it were not for New Vista Nursing, the Supreme Court might be more tempted to resolve Noel Canning on a narrow ground. A decision could go against the NLRB by holding that the Senate's 2011-2012 pro forma sessions shortened its recess into three-day periods. The Court might say such intrasession adjournments are too short to support recess appointments. But the Court would then have to address the impact of a twoweek recess, which was at issue in New Vista Nursing.

\footnotetext{
${ }^{22}$ McCulloch v. Maryland, 17 U.S. (4 Wheaton) 316, 407.
} 
The Justices presumably have a common preference not to produce administrative chaos;

New Vista Nursing might inadvertently nudge them toward a more modest path.

Conversely, the Supreme Court could decide that the pro forma sessions were truly of no significance in measuring the recess, and that the period from December
17, 2011, to January 23, 2012, was Congress's functional intersession recess, notwithstanding the technicalities. This would have allowed the Court to dodge the intrasession recess question, which New Vista Nursing would now require it to face.

But arguably, the biggest impact of the New Vista Nursing on the resolution of Noel Canning may be the degree to which it focuses the court's attention on just how much legal uncertainty the Court could create by holding intrasession recess appointments invalid. Hundreds and hundreds of NLRB actions are potentially at stake. The Justices presumably have a common preference not to produce administrative chaos; New Vista Nursing might inadvertently nudge them toward a more modest path. 